\title{
SPECIAL PROGRAM IN SPORTS ON THE LIFE SKILLS DEVELOPMENT OF STUDENT-ATHLETES
}

\author{
Efren S. Abustan \\ Graduate School, Laguna State Polytechnic University, Santa Cruz, Laguna, Philippines
}

Article DOI: https://doi.org/10.36713/epra7540

DOI No: 10.36713/epra7540

\begin{abstract}
This study entitled Special Program in Sports on the Life Skills Development of student-athletes of Gov. Felicisimo T. San Luis Integrated Senior High School was conducted to specifically answer the following questions; What is the status of SPS student-athletes' profile in terms of; Age; Gender; Grade Level; Sports Events; Training Hours; and Level Competition? What is the level of aspects of Life Skill Development in terms of; Behavioral; emotional; Mental; Physical; and Social? Does the Special Program in Sports affect the life skills development of the junior high school student-athletes of Gov. Felicimo T. San Luis Integrated Senior High School?

The study utilized the descriptive method of research to determine the effect of Special Program in Sports on the Life Skills Development of student-athletes. The main source of data of this study was the survey questionnaire which was prepared by the researcher and statistically treated using simple descriptive statistics such as frequency, percentage, mean, standard deviation and multiple regression to determine the significant effect of SPS on the life skills development of junior high school student-athletes.

Letters were sent to the Schools Division of Laguna, for the permission and approval to conduct the study, and to the School Principal of Gov. Felicisimo T. San Luis Integrated Senior High School, for the distribution of questionnaires to the student-athletes.

Self-made questionnaires were prepared and was checked and validated by the thesis adviser and panel members.

Purposive sampling was used, and each member of the population had an equal chance of being included in the sample. The respondents were consisted of sixty-three student-athletes of Gov. Felicisimo T. San Luis Integrated Senior High School.

The result of the study offers literature and findings that may be useful on the conduct of future studies more particularly in the context of life skills development and Special Program in Sports.

Questionnaires were administered according to the number of respondents. With confidentiality, the gathered information was tabulated. Data was analyzed and interpreted by the researcher's statistician.

The implication of this research was to find out if a student-athlete undergoing the Special Program in Sports develop different life skills that were necessary in everyday life.

The result showed that the Special Program in Sports had no significant effect on the life skills development of junior high school student-athletes of Gov. Felicisimo T. San Luis Integrated Senior High School. Therefore, the null hypothesis was accepted. This means that the profile of the student-athlete to the life skills development not influenced by age, sex, grade level, sports events, training hours and level of competition.

KEYWORDS: Special Program in Sports, Life skills, Student-athletes
\end{abstract}




\section{SJIF Impact Factor 2021: 8.013| ISI I.F.Value:1.241| Journal DOI: 10.36713/epra2016 ISSN: 2455-7838(Online) EPRA International Journal of Research and Development (IJRD)}

\section{INTRODUCTION}

The number of students participating in sports is continually increasing. This growth is being driven in part by the general view that youth who engage in sports activities develop optimistic future aspirations. Though several researchers have agreed that sports and physical activities have the effect of promoting personal growth, the findings of their respective studies have been varied. Being on the field or court does not always imply that a person is developing in a positive way. Various sports experience can help to develop this outcome. As a result, it has been suggested that skills that combine the mind and body be taught alongside and through sports and other physical activities. To put it another way, there has been a push for "education by the physical" rather than "education of the physical." These abilities are known as life skills.

Life skills are a necessary part of being able to handle the demands of daily life in a constantly changing world. Over the years, drastic shifts in global economies have coincided with technological transformations, all of which influence education, the workplace, and our personal lives. Students need new life skills, such as the ability to deal with stress and anger, to cope with the growing speed and change of modern life. Over the course of their lives, today's students will have a variety of new careers, each with its own set of pressures and requirements for versatility. Life skills development helps students discover new ways of thinking and problem solving in daily life, consider the effect of their actions and encourages them to take responsibility for their actions rather than blaming others, create trust in both spoken and community teamwork and cooperation, discuss choices, make decisions, and understand why they make those decisions outside of the classroom, gain greater self-awareness and empathy for others.

The purpose of this study is to determine the effectiveness of the Special Program in Sports in developing the life skill of student athletes. The SPS program is implemented by the Department of Education to develop the talents of the youth in sports and in the areas of leadership and good sportsmanship. Schools with SPS shall offer a 4-year secondary level curriculum on the Basic Education Curriculum with specialization in Sports. The result of this study will be use as a basis of SPS to give more emphasis that aside from being great on a specific sport there is also life skills developed on student-athletes.

\section{OBJECTIVES}

This study aimed to determine the Life Skills Development of Junior High School Student-
Athletes on the Special Program in Sports at Gov. Felicisimo T. San Luis Integrated Senior High School. Specifically, this study sought answers to the following questions:

1. What is the status of SPS student-athletes' profile in terms of:

1.1 Age,

1.2 Gender,

1.3 Grade Level,

1.4 Sports Events,

1.5 Training Hour/s,

1.6 Level of Competition?

2. What is the level of aspects of Life Skill Development in terms of:

2.1 Behavioral,

2.2 Emotional,

2.3 Mental,

2.4 Physical,

2.5 Social?

3. Does the Special Program in Sports affect the life skills development of the junior high school student-athletes of Gov. Felicisimo T. San Luis Integrated Senior High School?

\section{METHODOLOGY}

The researcher used the purposive sampling technique wherein members of the population had an equal chance of being included in the sample. They were the student-athletes who were willing to share their opinion and experiences associated with Special Program in Sports.

The researcher reviewed relevant theories and literature related to the study. After which, the researcher prepared a research made questionnaire to elicit responses geared to answer the problems associated with the study.

For the assurance, validity and reliability of the major instrument, the researcher formally approached the Division Superintendent of the Schools Division Office of Laguna and the Principal of Gov. Felicisimo T. San Luis Integrated Senior High School to ask permission for the distribution of questionnaires to the junior high school studentathletes.

The questionnaire was validated through content validation. Content validation refers to the degree to which an assessment instrument is relevant to, and representative of, the targeted construct it is designed to measure. The distribution of questionnaires was done online through chat, email, text message or phone call. The participants were given instructions and assured of confidentiality after which they were given enough time to fill in the questionnaires. The response of the respondents was sent the same way it was distributed. Then after the data gathering and analysis were conducted, it was 
the collated, summarized and analyzed. The results were presented in textual, tabular and graphical form as necessary.

Statistical treatment was used to analyze and interpret the data given by the respondents. After the questionnaire was administered to respondents, all the data were gathered, analysed, tabulated and interpreted.

In determining the Status of SPS studentathletes' Profile, the researcher used the frequency distribution and percentage as pie graph. In determining the level of aspects of life skills development, the researcher used the mean and standard deviation. Multiple regression was used to determine the significant effect of the Special Program in Sports on the Life Skills Development of the student-athletes of Gov. Felicisimo T. San Luis Integrated Senior High School.

\section{RESULT AND DISCUSSION}

This chapter deals with the presentation, analysis and interpretation of data gathered to answer the sub problem relative to the main problem of this study on the life skills development of junior high school student-athletes of Gov. Felicisimo T. San Luis Integrated Senior High School.

\section{SPS STUDENT-ATHLETES' PROFILE \\ Student-Athletes' Age}

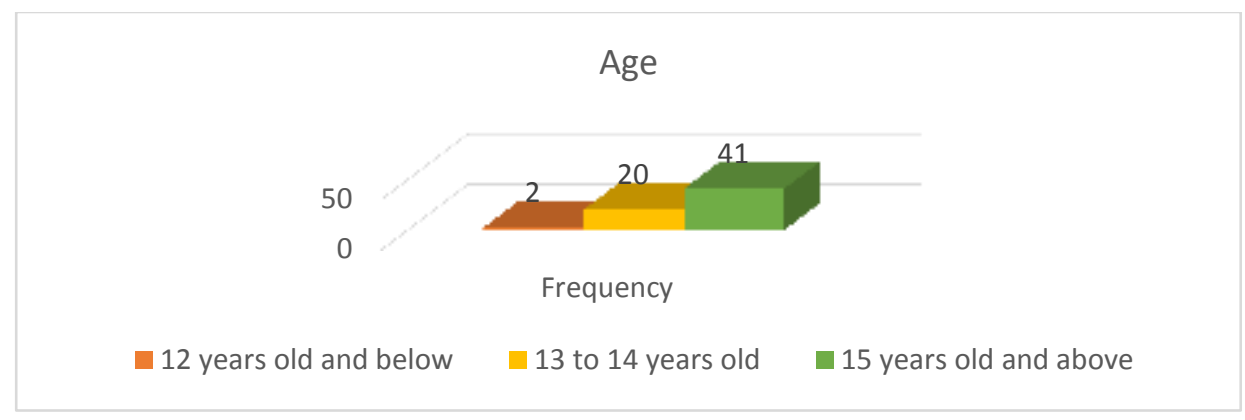

Figure 1. Status of SPS of student-athletes' profile in terms of Age

Graph shows that ages "15 years old and above" have the highest frequency of forty-one (41) or $65.08 \%$ of the total respondent. And have twenty (20) or $31.75 \%$ of the respondent are " 13 to 14 years old". While the ages "12 years old and below" received the lowest frequency of two (2) or $3.17 \%$ of the total respondents.

\section{Student-Athletes' Sex}

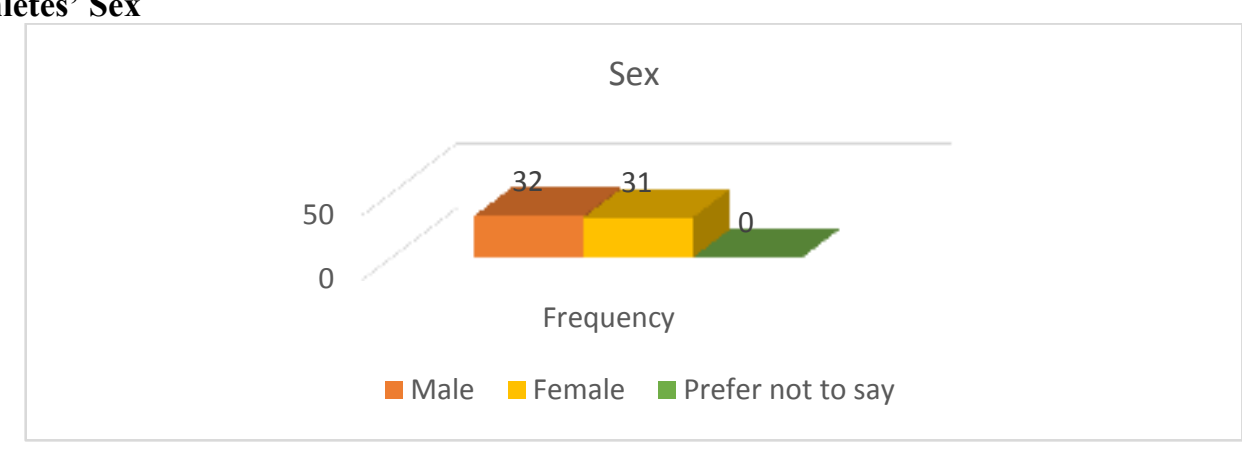

Figure 2. Status of SPS of student-athletes' profile in terms of Sex

Graph shows that sex "Male" has the highest frequency of thirty-two (32) or $50.79 \%$ of the total respondent. And have thirty-one (31) or $49.21 \%$ of the respondent are "Female". While the sex "Prefer not to say" received none (0) or $0.00 \%$ of the total respondents. 
Student-Athletes' Grade Level

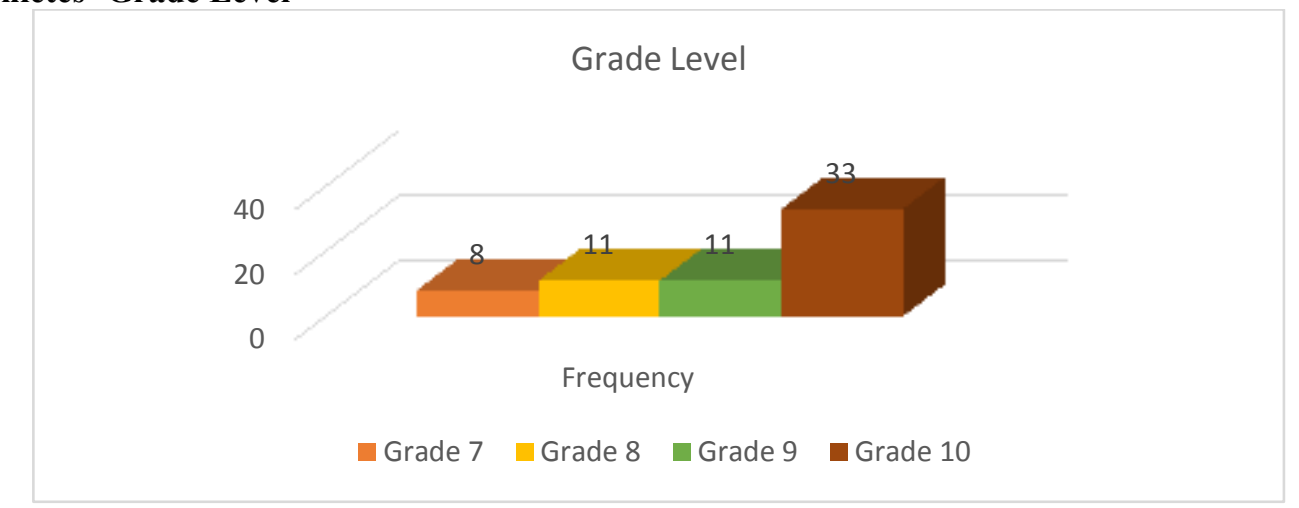

Figure 3. Status of SPS of student-athletes' profile in terms of Grade Level

Graph shows that level "Grade 10" have the highest frequency of thirty-three (33) or $52.38 \%$ of the total respondent. And each have eleven (11) or $17.46 \%$ of the respondent are "Grade 8" and "Grade
9". While the level "Grade 7" received the lowest frequency of eight (8) or $12.70 \%$ of the total respondents.

\section{Student-Athletes' Sports Events}

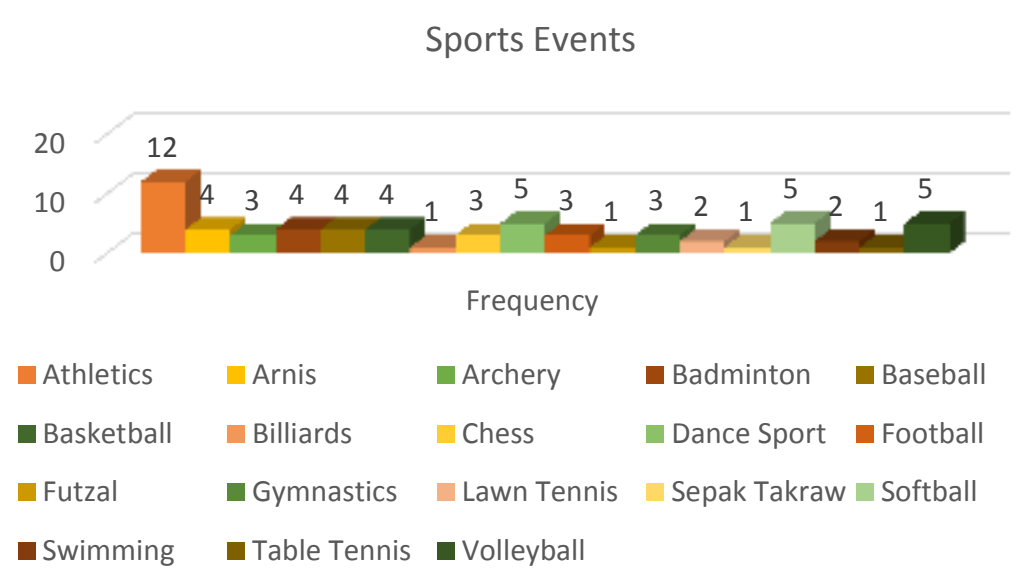

Figure 4. Status of SPS of student-athletes' profile in terms of Sports Events

Graph shows that sports "Athletics" have the highest frequency of twelve (12) or $19.05 \%$ of the total respondent. And each have five (5) or $7.94 \%$ of the respondent are "Dance Sports", "Softball" and
"Volleyball". While the sports "Chess", "Gymnastics", "Sepak Takraw" and "Table Tennis" received the lowest frequency of one (1) or $1.59 \%$ of the total respondents.

Student-Athletes' Training Hour/s

Training Hour/s

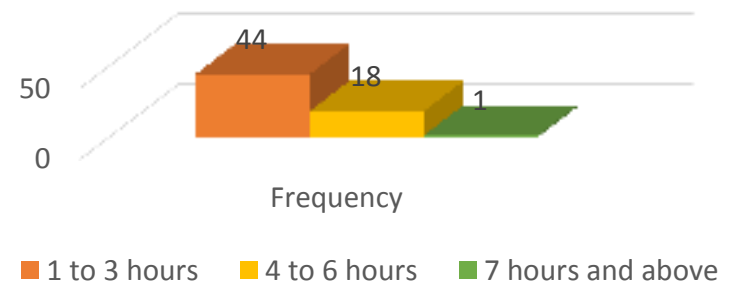

Figure 5. Status of SPS of student-athletes' profile in terms of Training Hour/s

(c) 2021 EPRA IJRD | Journal DOI: https://doi.org/10.36713/epra2016 | www.eprajournals.com|16 | 
Graph shows that training "1 to 3 hours" have the highest frequency of forty-four (44) or $69.84 \%$ of the total respondent. And have eighteen (18) or $28.57 \%$ of the respondent are " 4 to 5 hours".
While the training "7 hours and above" received the lowest frequency of one (1) or $1.59 \%$ of the total respondents.

\section{Student-Athletes' Level of Competition}

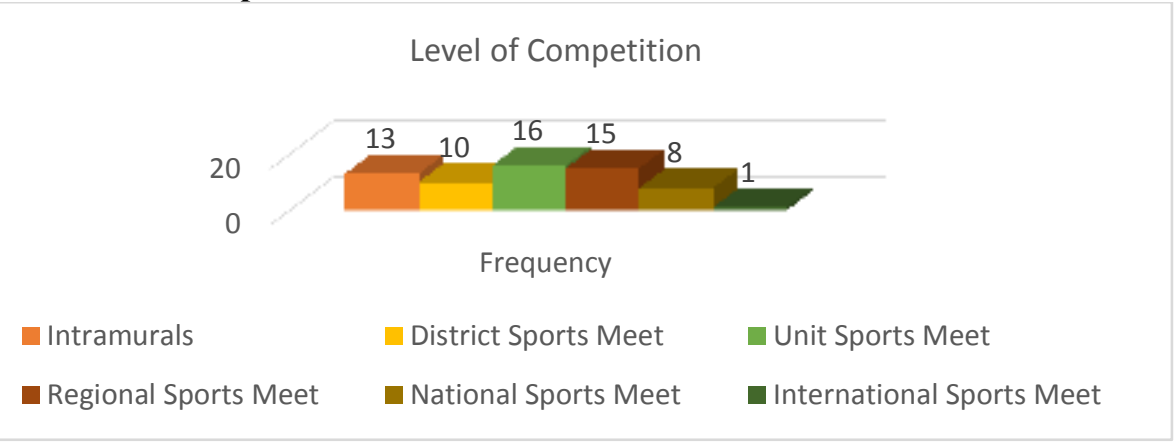

Figure 6. Status of SPS of student-athletes' profile in terms of Level of Competition

Graph shows that level "Unit Sports Meet” have the highest frequency of sixteen (16) or $25.40 \%$ of the total respondent. And have fifteen (15) or $23.81 \%$ of the respondent are in "Regional Sports Meet".
While the level "International Sports Meet" received the lowest frequency of one (1) or $1.59 \%$ of the total respondents.

\section{ASPECTS OF LIFE SKILLS DEVELOPMENT}

Table 1. Level of aspects of Life Skill Development in terms of Behavioral

\begin{tabular}{|l|c|c|c|}
\hline \multicolumn{1}{|c|}{ Statements } & Mean & SD & Remarks \\
\hline $\begin{array}{l}\text { I demonstrate sportsmanship by accepting whatever the result } \\
\text { might be without being enraged. }\end{array}$ & 4.37 & 0.81 & Always \\
\hline $\begin{array}{l}\text { I have an ability to adjust to any kind of situation and able to } \\
\text { handle pressure. }\end{array}$ & 4.29 & 0.77 & Always \\
\hline $\begin{array}{l}\text { I am consistent when it comes to discipline and commit myself in } \\
\text { everything that I do. }\end{array}$ & 4.48 & 0.72 & Always \\
\hline I manage my time wisely and balances my priorities. & 4.49 & 0.74 & Always \\
\hline $\begin{array}{l}\text { I treat people fairly and equally regardless of race, sex, social } \\
\text { status, etc. }\end{array}$ & 4.33 & 0.76 & Always \\
\hline $\begin{array}{l}\text { Overall Mean }=\mathbf{4 . 3 9} \\
\text { Standard Deviation }=\mathbf{0 . 7 5 9} \\
\text { Verbal Interpretation }=\text { Very High }\end{array}$ & & & \\
\hline
\end{tabular}

$\begin{array}{lll}\text { Legend: } & & \\ \text { Scale } & \text { Range } & \text { Remarks } \\ 5 & 4.20-5.00 & \text { Always } \\ 4 & 3.40-4.19 & \text { Often } \\ 3 & 2.60-3.39 & \text { Sometimes } \\ 2 & 1.80-2.59 & \text { Rarely } \\ 1 & 1.00-1.79 & \text { Never }\end{array}$

Based on the respondents' perceptions, the level of aspects of Life Skill Development in terms of Behavioral was generally very high. They manage time wisely and balances priorities have $(M=4.49$, $S D=0.74)$ and consistent when it comes to discipline and commit in everything they do with $(M=4.48$,

Verbal Interpretation
Very High
High
Moderately High
Low
Very Low

$S D=0.72)$. They have an ability to adjust to any kind of situation and able to handle pressure with $(M=4.29, S D=0.77)$; and this item got the lowest rating. All item indicators got a verbal interpretation of very high, as disclosed by the overall mean of 4.39 and supported with standard deviation value of 0.759 . 
Table 2. Level of aspects of Life Skill Development in terms of Emotional

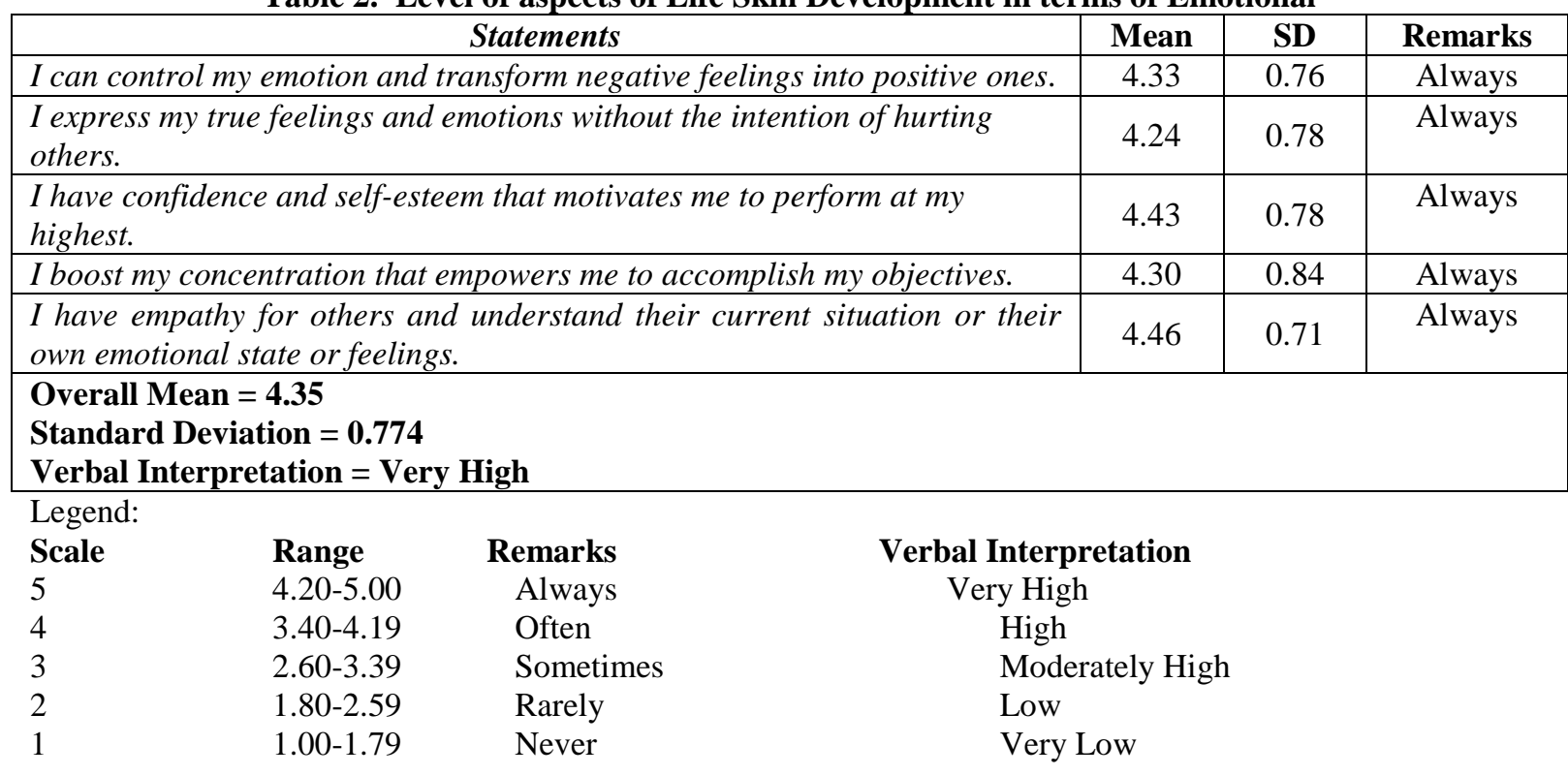

Based on the respondents' perceptions, the level of aspects of Life Skill Development in terms of Emotional was generally very high. They have empathy for others and understand their current situation or their own emotional state or feelings have $(M=4.46, S D=0.71)$ and have confidence and self-esteem that motivates to perform at the highest with $(M=4.43, S D=0.78)$. They express my true feelings and emotions without the intention of hurting others with $(M=4.24, S D=0.78)$; and this item got the lowest rating. All item indicators got a verbal interpretation of very high, as disclosed by the overall mean of 4.35 and supported with standard deviation value of 0.774 .

Table 3. Level of aspects of Life Skill Development in terms of Mental

\begin{tabular}{|l|c|c|c|}
\hline \multicolumn{1}{|c|}{ Statements } & Mean & SD & Remarks \\
\hline $\begin{array}{l}\text { I find ways to overcome challenges and hardships based on my } \\
\text { experiences. }\end{array}$ & 4.38 & 0.75 & Always \\
\hline $\begin{array}{l}\text { I maintain a high level of self-motivation to accomplish my goals and } \\
\text { eager to do so. }\end{array}$ & 4.48 & 0.72 & Always \\
\hline $\begin{array}{l}\text { I prefer long-term vision that allows me to use it in everyday } \\
\text { circumstances without being disturbed by other factors. }\end{array}$ & 4.49 & 0.67 & Always \\
\hline I keep a positive attitude and focus on the good things in life. & 4.63 & 0.58 & Always \\
\hline I do positive self-talk and reflect on myself. & 4.54 & 0.74 & Always \\
\hline $\begin{array}{l}\text { Overall Mean }=\mathbf{4 . 5 0} \\
\text { Standard Deviation }=\mathbf{0 . 6 9 3} \\
\text { Verbal Interpretation }=\text { Very High }\end{array}$ & & & \\
\hline
\end{tabular}

Legend:

$\begin{array}{lll}\text { Scale } & \text { Range } & \text { Remarks } \\ 5 & 4.20-5.00 & \text { Always } \\ 4 & 3.40-4.19 & \text { Often } \\ 3 & 2.60-3.39 & \text { Sometimes } \\ 2 & 1.80-2.59 & \text { Rarely } \\ 1 & 1.00-1.79 & \text { Never }\end{array}$

Based on the respondents' perceptions, the level of aspects of Life Skill Development in terms of Mental was generally very high. They keep a positive attitude and focus on the good things in life have $(M=4.63, S D=0.58)$ and do positive self-talk and

Verbal Interpretation
Very High
High
Moderately High
Low
Very Low

reflect on with $(M=4.54, S D=0.74)$. They find ways to overcome challenges and hardships based on my experiences with $(M=4.38, S D=0.75)$; and this item got the lowest rating. All item indicators got a verbal interpretation of very high, as disclosed by the overall 
Table 4. Level of aspects of Life Skill Development in terms of Physical

\begin{tabular}{|c|c|c|c|c|c|}
\hline \multicolumn{3}{|c|}{ Statements } & Mean & SD & Remarks \\
\hline \multicolumn{3}{|c|}{ I eat healthy and limit unhealthy food consumption. } & 4.44 & 0.69 & Always \\
\hline \multicolumn{3}{|c|}{$\begin{array}{l}\text { I have a healthy sleeping habit and make sure to complete the } \\
\text { required sleeping time. }\end{array}$} & 4.29 & 0.81 & Always \\
\hline \multicolumn{3}{|c|}{$\begin{array}{l}\text { I do a specific workout routine that is essential in managing my } \\
\text { body composition. }\end{array}$} & 4.40 & 0.82 & Always \\
\hline \multicolumn{3}{|c|}{ I stay hydrated by drinking water and limiting sugary drinks. } & 4.49 & 0.76 & Always \\
\hline \multicolumn{3}{|c|}{$\begin{array}{l}\text { I reduce sitting and limiting my screen time on using my mobile } \\
\text { phone and other gadgets. }\end{array}$} & 4.14 & 0.82 & Often \\
\hline \multicolumn{6}{|c|}{$\begin{array}{l}\text { Overall Mean }=4.35 \\
\text { Standard Deviation }=0.787 \\
\text { Verbal Interpretation }=\text { Very High }\end{array}$} \\
\hline \multicolumn{6}{|c|}{ Legend: } \\
\hline Scale & Range & Remarks & \multicolumn{3}{|c|}{ Verbal Interpretation } \\
\hline 5 & $4.20-5.00$ & Always & \multicolumn{3}{|c|}{ Very High } \\
\hline 4 & $3.40-4.19$ & Often & \multicolumn{3}{|l|}{ High } \\
\hline 3 & $2.60-3.39$ & Sometimes & \multicolumn{3}{|c|}{ Moderately High } \\
\hline 2 & $1.80-2.59$ & Rarely & \multicolumn{3}{|l|}{ Low } \\
\hline 1 & $1.00-1.79$ & Never & \multicolumn{3}{|c|}{ Very Low } \\
\hline
\end{tabular}

Based on the respondents' perceptions, the level of aspects of Life Skill Development in terms of Physical was generally very high. They stay hydrated by drinking water and limiting sugary drinks have $(M=4.49, \quad S D=0.76)$ and eat healthy and limit unhealthy food consumption with $(M=4.44$, $S D=0.66)$. They reduce sitting and limiting screen time on using mobile phone and other gadgets with $(M=4.14, S D=0.82)$; and this item got the lowest rating. All item indicators got a verbal interpretation of high and very high, as disclosed by the overall mean of 4.35 and supported with standard deviation value of 0.787 .

Table 5. Level of aspects of Life Skill Development in terms of Social

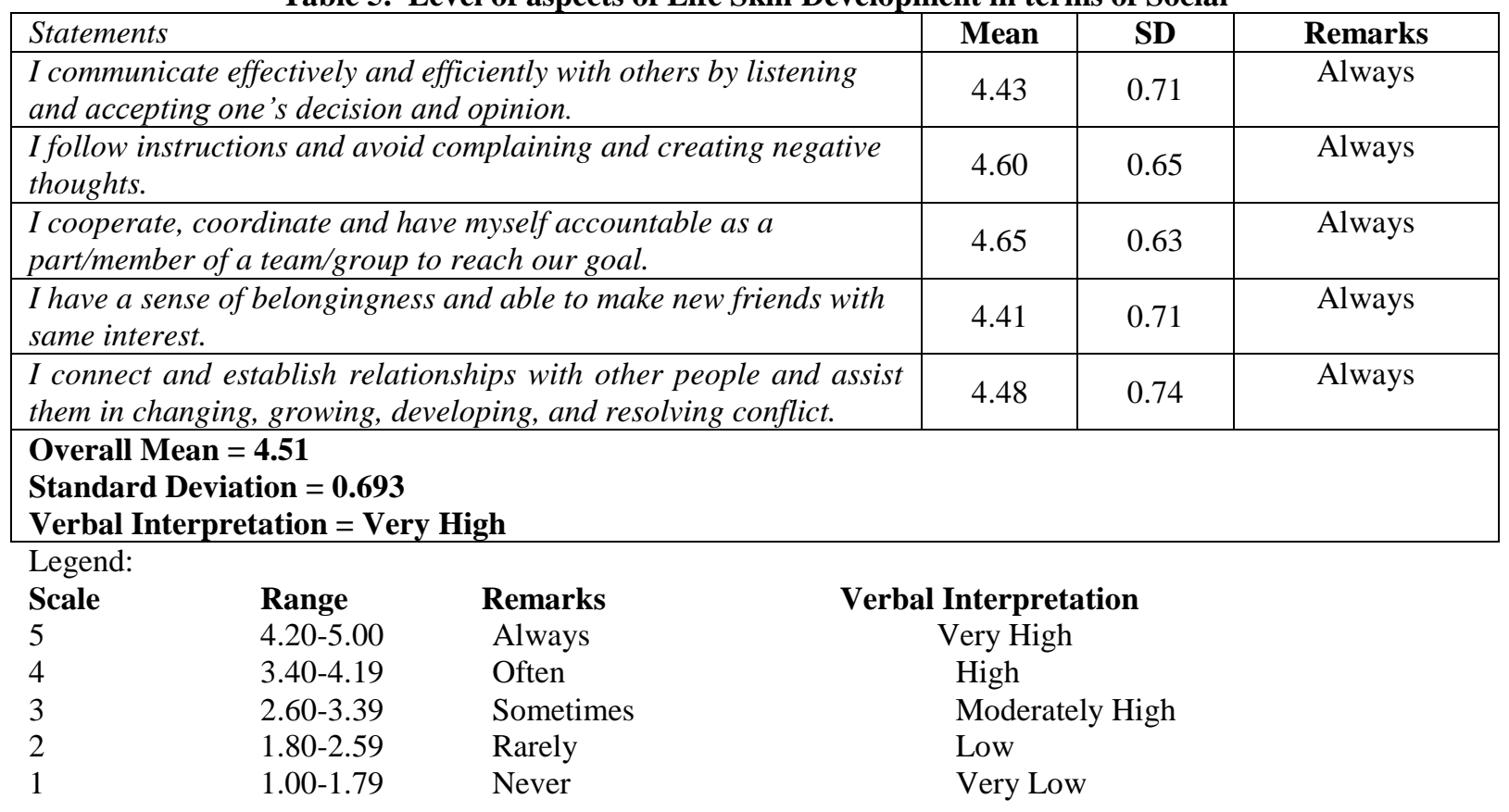


Based on the respondents' perceptions, the level of aspects of Life Skill Development in terms of Social was generally very high. They cooperate, coordinate and have accountable as a part/member of a team/group to reach our goal have $(M=4.65$, $S D=0.63)$ and follow instructions and avoid complaining and creating negative thoughts with
$(M=4.60, \quad S D=0.65)$. They have a sense of belongingness and able to make new friends with same interest with $(M=4.41, S D=0.71)$; and this item got the lowest rating. All item indicators got a verbal interpretation of very high, as disclosed by the overall mean of 4.51 and supported with standard deviation value of 0.693 .

\section{SIGNIFICANT EFFECT OF SPECIAL PROGRAM IN SPORTS ON THE LIFE SKILLS DEVELOPMENT OF STUDENT-ATHLETES}

Table 6. Regression analysis in the effect of the Special Program in Sports on the life skills development of the junior high school student-athlete of Gov. Felicisimo T. San Luis Integrated Senior High School

\begin{tabular}{|c|c|c|c|c|}
\hline Age & Beta & t-value & $\mathrm{p}$-value & Analysis \\
\hline Behavioral & 0.708 & 0.876 & 0.385 & Not Significant \\
\hline Emotional & -0.878 & -1.083 & 0.284 & Not Significant \\
\hline Mental & 0.451 & 0.700 & 0.487 & Not Significant \\
\hline Physical & -1.086 & -1.919 & 0.060 & Not Significant \\
\hline Social & 0.473 & 0.839 & 0.405 & Not Significant \\
\hline \multicolumn{5}{|l|}{ Sex } \\
\hline Behavioral & 0.140 & 0.295 & 0.769 & Not Significant \\
\hline Emotional & -1.041 & -2.191 & 0.033 & Significant \\
\hline Mental & 0.255 & 0.677 & 0.501 & Not Significant \\
\hline Physical & -0.304 & -0.918 & 0.362 & Not Significant \\
\hline Social & 0.478 & 1.446 & 0.154 & Not Significant \\
\hline \multicolumn{5}{|l|}{ Grade Level } \\
\hline Behavioral & 0.450 & 0.312 & 0.756 & Not Significant \\
\hline Emotional & -1.673 & -1.159 & 0.251 & Not Significant \\
\hline Mental & 0.990 & 0.863 & 0.392 & Not Significant \\
\hline Physical & -1.555 & -1.544 & 0.128 & Not Significant \\
\hline Social & 1.013 & 1.008 & 0.318 & Not Significant \\
\hline \multicolumn{5}{|l|}{ Sports Events } \\
\hline Behavioral & 2.564 & 0.916 & 0.363 & Not Significant \\
\hline EmotionaOl & -2.902 & -1.034 & 0.306 & Not Significant \\
\hline Mental & 1.928 & 0.864 & 0.391 & Not Significant \\
\hline Physical & -8.196 & -4.183 & 0.000 & Significant \\
\hline Social & -0.67 & -0.343 & 0.733 & Not Significant \\
\hline \multicolumn{5}{|l|}{ Training Hour/s } \\
\hline Behavioral & 0.551 & 1.315 & 0.194 & Not Significant \\
\hline Emotional & 0.590 & 1.402 & 0.166 & Not Significant \\
\hline Mental & -0.618 & -1.850 & 0.070 & Not Significant \\
\hline Physical & -1.091 & -3.717 & 0.000 & Significant \\
\hline Social & -0.109 & -0.371 & 0.712 & Not Significant \\
\hline \multicolumn{5}{|c|}{ Level of Competition } \\
\hline Behavioral & -0.160 & -0.126 & 0.900 & Not Significant \\
\hline Emotional & -0.349 & -0.274 & 0.821 & Not Significant \\
\hline Mental & -0.230 & -0.277 & 0.821 & Not Significant \\
\hline Physical & -1.421 & -1.602 & 0.115 & Not Significant \\
\hline Social & 0.536 & 0.605 & 0.547 & Not Significant \\
\hline
\end{tabular}

Adjusted R-Square: 0.8928

F-value: $\quad 104.31$

Sig.: $\quad 0.0000$ 


\section{SJIF Impact Factor 2021: 8.013| ISI I.F.Value:1.241| Journal DOI: 10.36713/epra2016

Results from Table 6 revealed that Life Skills Development had no effect on profile of the student-athlete. The beta coefficient indicates that for every standard deviation unit increase in Behavioral, Emotional, Mental, Physical and Social there is a corresponding unit increase in the profile of the student-athlete. The t-value of Behavioral, Emotional, Mental, Physical and Social is not significant having a p-value of greater than 0.05 level of significance.

This means that the profile of the studentathlete to the life skills development not influenced by age, sex, grade level, sports events, training hours and level of competition.

Based on the data, it is shown that there is "no significant effect of the Special Program in Sports in the life skills development of the junior high school student-athlete of Gov. Felicisimo T. San Luis Integrated Senior High School" at 0.05 level of significance. It shows that the null hypothesis stating that "There is no significant effect of the Special Program in Sports in the life skills development of the junior high school student-athlete of Gov. Felicisimo T. San Luis Integrated Senior High School" is accepted, it can inferred that there is "no significant" effect between them.

\section{CONCLUSION}

Drawn the results of the study, the null hypothesis stating that "There is no significant effect of the Special Program in Sports in the life skills development of the junior high school student-athlete of Gov. Felicisimo T. San Luis Integrated Senior High School" is accepted, it can infer that there is "no significant" effect between them.

\section{RECOMMENDATION}

Based on the conclusion drawn from the study, the following were hereby recommended:

1. Teacher-coaches may motivate the student-athletes to continue joining the program and be informed that it is a good opportunity for them to build life skills that will benefit them not only in their current situation but also in the future.

2. The teacher-coaches may continuously attend and join seminars and training related to the sports they were assigned to because they guide and train student-athletes and they play a significant role in helping athletes improve not only in sport, but also in their current situation and in whatever field they will choose in the future.

3. The school administration may ensure the efficient and effective implementation of the policies and guidelines regarding SPS. Also, they can facilitate team building activities for the studentathletes to boost not only their physical strength but also other aspects of life.

4. To the future researchers, a parallel study could be done to negate, confirm or improve the result of the present study.

\section{REFERENCES}

1. Açak, M. and Duz S. (2018). Adaptation of the effect of sport on life skills scale to Turkish culture. Journal of Inonu University Educational Sciences Institute, 5(9): 74-86. https://doi.org/10.29129/inujgse.360711.

2. Adachi, P. J., \& Willoughby, T. (2014). It's not how much you play, but how much you enjoy the game: The longitudinal associations between adolescents' self-esteem and the frequency versus enjoyment of involvement in sports. Journal of Youth and Adolescents' Self-Esteem and the Frequency Versus Enjoyment of Involvement in Sports

3. Camire, M. \& Staps, D. (2015). Reconciling competition and positive youth development in sport. Reconciling competition and positive youth development in sport | Cairn International Edition (cairn-int.info)

4. Camp North Star Maine (2017) Learning Life Skills Through Sports

https://campnorthstarmaine.com/2017/03/23/lear ning-life-skills-sports-athletics/

5. (5) Cando, J.D. and Cagurin, G.B. (2017). Health Optimizing Physical Education.

Mutya Publishing House, Inc.

6. Carson, S., and Gould, D. (2008). Life skills development through sport: Current status and future directions. International review of sport and exercise psychology 1 (1), pp. 58-78

7. Coakley, J. (2016). Positive youth development through sport: Myths, beliefs, and realities. In N. L. Holt (Ed.), Positive youth development through sport (pp. 21-33). London: 599 Routledge

8. Cronin, L.D. and Allen, J.B. (2015). Developmental experiences and well-being in sport: The importance of the coaching climate. The Sport Psychologist, 29(1): 62-71. https://doi.org/10.1123/tsp.2014-0045.

9. Deci, E. L., \& Ryan, R. M. (2000). The "what" and "why" of goal pursuits: Human needs and the self-determination of behavior. Psychological Inquiry, 11, 227-268.

10. Deweese, Hornsby and Stone (2015), The training process: Planning for strength-power training in track and field. Part 1: Theoretical Aspects. Journal of Sport and Health Science, Volume 4, Issue 4, Pages 308-317

11. Eime, R.M., Young, J.A., Harvey, J.T., Charity M.J., and Payne, W.R. (2013). A systematic review of the psychological and social benefits of participation in sport for children and adolescents: Informing development of a 
conceptual model of health through sport. International Journal of Behavioral Nutrition and Physical Activity, 10(1): 1-21. https://doi.org/10.1186/1479-5868-10-98

12. Eime, R.M., Harvey, J.T., Charity, M.J., Casey, M.M., Westerbeek, H., \& Payne, W.R. (2016). Age profiles of sport participants BMC Sports Science, Medicine and Rehabilitation volume 8, Article number: 6

13. Fox, C., Barr-Anderson, D., Neumark-Sztainer, D., \& Wall, M. (2010). Physical activity and sports team participation: Associations with academic outcomes in middle and high school students. Journal of School Health, 80(1), 31-38.

14. Ghildiyal, R. (2015). Role of sports in the development of an individual and role of psychology in sports. Mens Sana Monographs, 13(1): 165-170. https://doi.org/10.4103/09731229.153335 .

15. Goldsmith, E.B. (2000). Resource management for individuals and families. 2nd Edn., United States: Wadsworth Thomson Learning.

16. Gould, D. (2014). Fostering Life Skills \& Youth Leadership Through Sport. https://www.sportsingapore.gov.sg/Imedia/SSC/Corporate/Files/Athletes-andCoaches/For-Coaches/CoachDevelopment/Coaching-LearningResources/Fostering-Life-Skills-and-YouthLeadership-through-Sport.pdf

17. Hardy, L., Barlow, M., Evans, L., Rees, T., Woodman, T., \& Warr, C. (2017). Great British medalists: Psychosocial biographies of superelite and elite athletes from Olympic sports. Progress in Brain Research, 232, 1-119.

18. Hayden, L. A., Whitley, M., Cook, A. L., Dumais, A., Silva, M., \& Scherer, A. (2015). An exploration of life skills development through sport in three international high schools. Qualitative research in sport, exercise and health

19. Health Direct (2020) Developing life skills through

sports.https://www.healthdirect.gov.au/developin g-life-skills-through-sports

20. Holt, N. (2013) Can Sport Help Develop Life Skills? Designing an Effective Training Program https://www.wise-qatar.org/sports-educationnick-holt/

21. Kasper, K. (2019) Sports Training Principles. Current Sports Medicine Reports. Volume 18 Issue 4 - $p$ 95-96 doi: 10.1249/JSR.0000000000000576

22. Ken Hodge, Steven Danish, and Julia Martin (2012). Developing a Conceptual Framework for Life Skills Interventions. DOI: 10.1177/0011000012462073

23. Ladaran T.Y. (2018) School Sports Program. School Sports Program - PHYSICAL EDUCATION (weebly.com)

24. Memmert D., Roth K. (2007) The effects of non- specific and specific concepts on tactical creativity in team ball sports. J Sports Sci; 25(12): 1423-1432

25. Pestano, R., and Vargas, D. (2021) Problems encountered in the implementation of Sports Development Program in Juan $R$. Liwag Memorial High School https://ssrn.com/abstract $=3834510$ http://dx.doi.org/10.2139/ssrn.3834510

26. Pierce S., Gould, D., \& Camire, M. (2017) Definition and model of life skills transfer. International Review of Sport and Exercise Psychology 10(1):186-211 DOI:10.1080/1750984X.2016.1199727

27. Rudman, W.J. (2021) Age and Involvement in Sport and Physical Activity in Sociology of Sport Human Kinetics DOI: https://doi.org/10.1123/ssj.6.3.228

28. Sanz A., \& Guerrero A. (2005). Futsal: meaningful tasks for integrated training. From traditional to modern training. Madrid (Spain). Ed. Editorial Gymnos;

29. Sport and Health Science (2015) The training process: Planning for strength-power training in track and field. Part 1: Theoretical aspects. Journal Volume 4, Issue 4, December 2015, Pages 308-317 https://doi.org/10.1016/j.jshs.2015.07.003

30. Stevenson, B. (2010). Beyond the classroom: Using Title IX to measure the return to high school sports. PSC Working Paper Series, PSC 10-03. http://www.nber.org /papers/w15728.pdf

31. Sulong Udyong (2014) Special Program in Sports. http://www.udyong.gov.ph/index.php?option=co $m \_$content $\&$ view $=$ article $\& i d=5460$ : special program-in-sports\&catid $=90 \&$ Itemid $=1267$

32. Tungpalan, K. A. and Luna, G.L. (2013). Fundamentals of Sports. St. Andrew Publishing House.

33. World Health Organization and UNESCAP (2012). A quantitative investigation on life skills internalization and generalization in SportDevelopment. Master thesis in Sport Sciences Department of Coaching and Psychology. 